\title{
A Refugee as a Status Symbol: The Case of the Palestinian Refugees
}

\author{
Nitza Nachmias \\ Tel Aviv University, Tel Aviv, Israel
}

\begin{abstract}
The refugee problem has existed for centuries and has created great suffering for both refugees and for those who have tried to assist them. There are an estimated 11-12 million refugees and about 30 million internally displaced persons in the world today, and approximately 70\% of them are in Africa and the Middle East ${ }^{1}$. The most protracted and complicated refugee situation is the case of the Palestinians who ceased to be stateless refugees decades ago but insisted on being identified as "refugees". The Palestinians transfer the refugee identity from one generation to the next, as a status symbol and an honored identity. In fact, the descendants of the 800,000 Palestinians, who fled their homes in Palestine in 1948, have long been settled in the countries of their residence, but they still identify themselves as "Palestinian refugees" and they carry a refugee Id card as an honorary membership card. From early childhood, Palestinian children are socialized to adopt the identity of "refugees", and idealizing of returning to the homeland of their distant ancestors. The have developed a self-concept, self-regard, and self-identity based on the refugee-narrative. They feel that giving up the refugee identity could lead to the elimination of the Palestinian identity and nationality.
\end{abstract}

Keywords: refugee, Palestinan refugees, refugee identity, UNRWA (United Nations Work and Relief Agency for the Palestinian refugees), stateless narrative

\section{Introduction}

"We see ourselves radically differently in different contexts. Everyone struggles with that existential plum, who am I?"

Walt Whitman

The refugee problem has existed for centuries, and has created great suffering for both refugees and those who have tried to assist them. No region or continent is free of refugees-people caught between danger at home and loss of identity in a strange land. Feelings of fear of persecution, harassment, and oppression have led millions to flee their homes and seek safety in strange societies. The stark images of tens of thousands of people fleeing terror and murder inflicted by their own government because of their ethnic, religious, or political affiliation have been haunting the international community for over a century. Where there is no state authority to provide protection against such atrocities, the international community becomes essential. After WWI, in the wake of the massive refugee problem, the League of Nations entrusted the protection of the refugees to the International Red Cross. Following WWII, the new UN (United Nations) system created a global refugee protection regime, through the establishment of UNHCR (the United Nations High Commissioner for

Nitza Nachmias, Ph.D., professor, MA program on Conflict Resolution, Faculty of Social Science, Tel Aviv University. ${ }^{1}$ UNHCR publications, 2013. 
Refugees). Some of the largest refugee migrations in the 20th century occurred after the Russian Revolution of 1917, when approximately 1.5 million Russians who opposed communism left Russia; one million Armenians fled Turkey between 1915 and 1923 to escape persecution and genocide. Following the establishment of the People's Republic of China in 1949, two million Chinese fled to Taiwan and Hong Kong; and the world's largest population transfer in history occurred in 1947 when 18 million Hindus from Pakistan and Muslims from India were moved between the newly created countries of Pakistan and India. Between 1946 and 1949, one million Jewish survivors of the Holocaust moved to Israel from Europe, while one million Jewish refugees fled to Israel from Arab states in the Middle East. Finally, approximately 3.7 million East Germans fled to West Germany between 1945 and 1961, when the Berlin Wall was constructed. The descendants of these refugees wished to shed their refugee identity both legally and socially, as soon as possible. Socially, they integrated into the societies of their residence; legally, the "Refugee Convention" introduced the "Cessation Cause", explaining when a refugee is no longer a refugee. According to the Cessation Clause, changes in the personal circumstances of a refugee, namely, if the refugee willingly obtained a passport or residency in another state, he/she is no longer "refugees". Following the cessation clause, the Palestinian descendent of the 1948 refugees are not refugees. So why do they insist on their "refugee status”? During the past 66 years, the number of the descendants of the original 1948 refugees grew to over five million! This is due to the fact that the Palestinian community population growth rate is among the highest in the world ${ }^{2}$. Recently, the issue of the Palestinian refugees has gained center stage in the Israeli-Palestinian peace negotiations. The trigger was Israel's demand that PA (the Palestinian Authority) recognizes Israel as a Jewish State. The implication of such acknowledgment is the complete renunciation of the "right of return" for the five million Palestinians holding a UN refugee ID card. PA immediately rejected this demand reiterating its adherence to the principle that the five million refugees' right of return is not negotiable. This dispute has been lingering for over six decades and it does not seem to lose its bite. The recent controversy showed once again that the most contentious issue in the protracted Israel-Palestinian conflict is the issue of the refugees.

\section{Historical Background}

In 1948, following the first major Israeli-Arab War, about 800,000 Palestinians fled their homes in Palestine, and settled in neighboring Arab countries. In the absence of the soon-to-be-formed UNHCR (formed in 1951), and in recognition of the important role that the UN GA (General Assembly) played in the Israeli-Arab conflict, and its special responsibility to the consequences of the Partition resolution ${ }^{3}$, GA created UNRWA (the United Nations Relief and Work Agency) for the Palestinian refugees ${ }^{4}$. The agency's mission included two tasks: first, providing short-term humanitarian assistance (shelter, food, medical care) to the refugees, and second, to work toward a durable, final solution to the refugee problem. Both the first and the second tasks have been achieved and completed during the 1950s, and the 1960s, when all the 1948 refugees have been settled in permanent homes in the countries of their residence and most of them even became citizens

\footnotetext{
${ }^{2}$ Palestinian population growth is $1.88 \%$ per year (2013). According to UNDP, Arab Human Development Report (2010), “The population of the Arab countries nearly tripled between 1970 and 2010, climbing from 128 million to 359 million. According to the medium variant projection, the Arab Region will have 598 million inhabitants by 2050, increasing by two-thirds or 239 million more people than in 2010”.

3 The Partition Plan and UNSCOP (the United Nations Special Committee on Palestine), created on May 15, 1947.

${ }^{4}$ UNRWA was created by the UN General Assembly in 1949 to provide emergency aid to the Palestinian refugees. It has been in existence ever since.
} 
of these countries. However, due to political considerations, UNRWA's ad hoc humanitarian mission was not terminated, and UNRWA has been continuing to provide social services to the descendants of the 1948 refugees in Jordan, Syria, Lebanon, the West Bank, and Gaza. UNRWA also has been continuously issuing refugee ID cards to every Palestinian, declaring that he/she is a descendent of the 1948 refugees UNRWA does not vet its clients; traditionally, a personal statement was accepted as a fact. This unique scheme not practiced by UNHCR, or any of the UN agencies, was initiated by URWA in 1948, as a bureaucratic tool to distinguish between eligible bone fide refugees to local, non-refugees residence. In 2014, the second, third and now forth generations of the descendants of the 1948 refugees continue to apply, and to receive, a Palestinian ID card. While the new bearers of the refugee ID cards never fled their homes, never experience a threat to their lives, and are settled in the countries of their residence, they define themselves and are defined by UNRWA as refugees. UNRWA's list has been growing exponentially and now stands at over five million people, who claim that they are bone fide Palestinian refugees entitled to the "Right of Return". This anomaly is feeding the Palestinian refugees narrative and is being fed by it. It is a psychological and sociological phenomenon that transcends the financial factor and the tentative right for monitory compensations for the descendants of the 1948 refugees. These refugee ID cards became a quasi-identity card, an advantage, and a status symbol, that parents and grandparents bequest to their children and grandchildren. Being a Palestinian refugee has become a social status, a birth right that newborn Palestinians are awarded upon birth.

\section{The Uniqueness of the Palestinian Refugee Issue}

Table 1

General View

\begin{tabular}{lcccl}
\hline & No. of clients & No. of countries & No. of employees & Budget (2014) \\
\hline UNRWA & 5 million & 5 & 22,000 & $\$ 1,277$ (bl.) \\
UNHCR & 34 million & 125 & 7,685 & $\$ 5,335$ (bl.) \\
\hline
\end{tabular}

Notes. ${ }^{*}$ Only about 3 million receive services; ${ }^{* * *}$ including \$ 290 million special fund or Syrian refugees.

The prolonged Palestinian refugee problem is unique for two main reasons: The issue has factual, legal, and tangible aspects, and non-tangible, cognitive-emotional, psychological aspects. The factual-legal aspects concern mainly the legal "right of return" of the descendants of the 800,000 Palestinians who fled the Israel-Arab war in 1948. The 1951 Refugee Convention does not recognize settled persons, citizens of a third country as refugees. The Palestinian refugee ID card has no legal status. Persons whose great-grandfather was a refugee cannot claim asylum rights or the right to return to their great-grandfather hometown. Such a claim would create havoc in Europe and in India, among other states. The Palestinian persons who themselves, and whose parents and grandparents never fled their homes for fear for their lives on basis of religion, race or ethnicity, and who are settled in the countries where their ancestors found refuge cannot claim refugees' status. In fact, the contrasting behavior is the norm. Descendants of refugees' exhibit desire to remove themselves from the refugee experience of their forefathers; they do not want to dwell on the family's ghastly past. In Israel, survivors of the Holocaust rarely discussed their horrible past and the second and third generations of Israelis see themselves removed from the image of the European Jewish refugees. The Palestinian community is unique in their holding on for generation to a refugee status. It is a psychological and legal anomaly because the UN has no authority to grant legal refugee status to individuals or to groups of people. The prerogative to grant 
legal, refugee status is given only to legitimate government ${ }^{5}$. The UNHCR provides aid to tens of millions of refugees and internally displaced persons, but has no authority and indeed the UNHCR does not issue refugees' ID cards. The Palestinians are the only persons who have been granted refugee status by a UN agency.

The second unique characteristic of the Palestinian refugee's problem is a non-tangible, cognitive-emotional attribute. There is a tendency to see all refugees from a given country or region as a homogenous group, to label them Palestinian, Cambodian, Rwandan, etc., and not to look beyond the label. The Palestinian refugees of 1948 are a case in point. Like most refugee groups, they have been subdivided into many clans, tribes, families, that differed greatly, had different experiences, and may even have been hostile to one another. Albeit, the Palestinian refugee experience created a common narrative that has been shared and adopted by all the subdivision of the Palestinian society. The 1948 refugees have indeed experienced, among other distressing factors, the destructive trauma of fear for their lives, dislocation, loss of communal identity, humiliation, being stateless and without any clear national or social status, and becoming depended, at least initially, on charity. Since 1948, and throughout the past six decades, the Palestinian community has recovered from the war and the refugee experience, and like other refugee groups, such as the survivors of the Holocaust, the refugees of the Chinese revolution, the India-Pakistan war refugees, etc., the Palestinian refugees have been integrated and settled in the various countries of their residence. Descendants of non-Palestinian refugee groups would probably be offended if we will address them as "refugees", since they have become proud citizens of their new homeland. All the while, the Palestinian people and the Arab states have been continuously and consistently fostering and nurturing the narrative of the "Palestinian refugees", namely, perpetuating the myth that all the Palestinians wherever they live, are still refugees, and they have a UN refugee ID card to prove it. The title "refugee" has become the representative of the Palestinian national identity, their national pride, and their raison d'etre; this narrative says that the Palestinians, who in 1948 became refugees, have never ceased to be refugees. They narratively depict pre-1948 Palestine as a fertile green land, with water springs meandering around, full of orchards, vineyards, etc.. This green and fertile picture is in complete contrast to reality. Before 1948, Palestinian was partly arid land, partly desert land, and the north was marshes infested with Malaria mosquitoes. But the narrative of a land of "milk and honey" has been transmitted from one generation to the next, from father to son, etc..

Legally, the descendants of the 1948 generation are not refugees, since they are citizens or residents of the country where they and their families have been residing for three or even four generations. UNRWA, however, continues to issue refugee ID cards albeit, with no legal authority. While the refugee ID card has neither legal basis nor legal value, it has become a status symbol, a proud and distinguished membership card in a prestigious club: "the Palestinian refugee club". Until his death, Professor Edward Said insisted that he is a "Palestinian refugee" while for most of his life he was a US citizen and a distinguished Colombia University professor. This phenomenon is common among Palestinian living in the diaspora. Most Palestinian families apply for and receive a UN Palestinian refugee ID card, regardless of where the family resides, and UNRWA issues the requested ID cards without vetting the applicants. The cards do not have an expiration date, or a renewal requirement, thus many deceased persons are still listed as living refugees. The practice has been going on for six decades and the number of holders of UNRWA's refugee ID card has grown exponentially. Almost every Palestinian child receives upon his/her birth the title "refugee" as if it was a knighthood. It seems that the

${ }^{5}$ See the Refugee Convention of 1951. 
Palestinians have turned the 1948 war experience into a "birth of a nation" event, and the refugee ID cards prove that they are the true descendants of the "first generation free Palestinian", namely the pilgrims of the Palestinian experience; the Mayflower generation. The Palestinian community does not see this behavior anomaly as incomprehensible or legally inexplicable. Moreover, research shows that the motivation to maintain and perpetuate this unique behavior is not financial, and the insistence and drive of the millions of Palestinians living in the diaspora, not to give up their Palestinian refugee status, is not propelled by economic considerations. The prospects of receiving vast retributions or financial compensation for lost land and property are only secondary. Palestinians who were interviewed in 2011 in the West Bank, did say that they should be compensated by Israel for the destruction of their villages, however, the most painful point for them was the loss of their culture, nationality, respect, and identity. Adherence to the refugee status is an emotional response to these feelings of humiliation and loss of self and communal identity. They "equated justice with the 'right of return' ...they were not only referring to the physical land lost. Rather, return referred to the much broader claim for the restoration of life as it had been, a metaphoric return to the conditions lost rather than the physical move to previous properties" (Beckerle, 2012). It is clear that economic and financial considerations are not the main reasons why the Palestinian people will not give up their refugee status. Being a Palestinian refugee has become a status symbol, a national and communal identity, a statement that the Palestinian nation will be revived and rise to its past glory. We believe that the "refugee narrative" serves cognitive and emotional needs that enable this phenomenon to continue and be bequeathed to future generations. Exile and other forms of territorial displacement are always undesirable, painful, and if possible, forgotten. The Palestinian community, however, gave the term "refugee" a completely new meaning.

\section{Who Is a Refugee?}

The 1951 Convention Relating to the Status of Refugees defines a refugee as any person who: "owing to well-founded fear of being persecuted for reasons of race, religion, nationality, membership of a particular social group or political opinion, is outside the country of his nationality and is unable or, owing to such fear, is unwilling to avail himself of the protection of that country”. This definition does not include displaced persons who have not crossed an international border nor does it include those who fled, internally or externally, not for fear for their lives but to get out of the way of war or civil strife. This legal distinction in the laws and treaties that limits the refugee experience or behavior, is all too often unimportant. In real life situations, the refugee category is defined by the trauma and stresses, persecution and danger, losses and isolation, uprooting and change in the behavior, feelings, and perception of the world around the refugees. While refugees come from extremely diverse cultures, traditions, ethnicity, religion, and political systems, studies show that the refugees' groups share one basic tenet: They all had to flee their homes due to horrifying environmental circumstances. Thus, it can be said that a refugee experience produces what we can call a refugee behavior (David, 1969). Refugees, like all persons, act, and these individual actions occur in the context of the social structure within which the individuals exist. These processes constitute the social structure of society that emerges from individual actions, as those actions are patterned across individuals and over time. These structures consist of the full set of patterns of action, interaction and resource transfers among all members of the community. In this way, social structure is a very abstract idea. It is not something we experience directly. We are not directly tuned to these patterns as they occur across persons and over time. But, we can become aware of these patterns as well as recognize them, name them, and attend to them. They become part of our everyday language and they encompass social 
structure such as: "the poor", "the homeless", "the opinion leaders”, and "the middle class”. These structures do not have a formal, legal structure, but they are recognizable by their behavior and actions. Refugees' patterns of action differentiate them from other groups mainly because they are denied access to positions of power, authority and influence. Nevertheless, refugees are also parts of a social structure and they affect and are being affected by the other structure of society.

The refugees' experience creates identifiable and often identical patterns of behavior and sets of causalities because all refugees experience life on the run and total dependence on aid from organizations or social groups. This dependence has psychological and sociological consequences that can be defined as socially patterned behavior. We can develop a general perspective that looks at consistencies and shared attributes in the refugee experience and behavior. Generally, refugees' mental and physical state, as well as their reactions to their dire conditions, does recur in most contexts, times, and regions.

In the case of the Palestinian community, the above discussion is accurate for the first and the second generations. They did indeed, experience exile, territorial displacement, homelessness, and in the early years, even shortages of food and shelter. UNRWA was created to respond to the suffering, cope with the immediate threat to human lives, and provide lifesaving aid to the 800,000 persons that fled to refugee camps in the West Bank, Jordan, Egypt (GAZA), Syria, and Lebanon. Very expeditiously, between 1949 and 1952, the entire refugee population was moved to permanent housing constructed by UNRWA with donations from a variety of countries. However, the descendants of the 1948 refugees refuse to shed the "refugee narrative" and they willingly adopt and embrace it. In reality, they are not in exile but they view themselves and are viewed by the outside world as "refugees". The Palestinian national identity as well as the Palestinian individual identity are a corollary of the refugee narrative, transmitted from one generation to the next with piousness. Using the 1948 displacement narrative, the Palestinian community of today has succeeded to influence the outside world to accept their refugee identity.

\section{UNRWA and the Palestinian: A Case of Mutual Dependence (Interdependence)}

As mentioned earlier, refugees are totally dependent on external aid to secure their food, shelter, and personal safety. This is an obvious lop-sided relationship between a patron and a client ${ }^{6}$. The patron, in the relationship enjoys a high level of control over his client's state of affairs and actions. Often, patronage could render the patron with prestige, power, and influence, while the client is provided with his basic needs. In a dependence system, the client wellbeing is ensured through a mixture of economic and strategic ties, which are covered by the general terms "patronage" and "clientage". The relationships usually are institutionalized both politically and economically, while the weaker-client has to follow the stronger-patron's rules. In the last century, the ties of patron-client were basic to the Cold War system, and the West and the USSR (Union of Socialist Soviet Republics) each had their clients. Its essence has not been the fixed and contractual but rather the informal and flexible relationships. The patrons gave their clients a degree of political power, through their support of the patron in his external political activities. The patron could become a cultural broker, and develop a system of obligations that are moral rather than monetary. Clients could become wealthy, or in the case of the Palestinian, established and prosperous citizens of a third country, but they do not lose their jurally status as clients. The argument continues to state that ultimately, the clients and the patrons become entangled in the political process, lose their independent, professional nature, and, in fact, become an extension of each other.

\footnotetext{
${ }^{6}$ The roots of the patron-client relationship have been traced by some to the dependence of plebeians on patricians in the Roman
} Empire. 
Despite stressing the asymmetry of the patron-client relationship, it is possible for the patron and the client to develop a mutual dependence system, namely the patron and the client's interests are intertwined and the patron is as dependent on his client as the latter is dependent on his patron. Our study shows that an interdependence system has evolved between the Palestinian clients and their patron, UNRWA. The agency has been providing social services to the Palestinian community for 65 years, and has become dependent on them for its survival and continued institutional existence. As a method of survival, UNRWA has been perpetuating and nurturing the "refugee narrative" keeping the Palestinians dependent on their educational, health and welfare services. UNRWA continues to issue "refugee ID cards" to Palestinian newborn, multiplying the number of their clients and securing their institutional existence as an aid agency to the "Palestinian refugees". UNRWA, the patron, has grown to become a vast and entrenched bureaucracy, constructing and running about 1,000 schools, hundreds of health clinics, employment agencies, welfare services, women's projects, job training projects, summer camps for children, small loans apparatus, etc.. To carry out this complex network of activities, UNRWA has an annual budget of about a billion DLS, and it employs over 30,000 Palestinian workers. It is imperative for UNRWA, as an organization to maintain a large body of "Palestinian refugees" clients, lest its raison d'etre will vanish.

The patron-client relationships that UNRWA has developed with its Palestinian clients are far removed from UNRWA's original mandate and agenda. UNRWA's mission was to facilitate the execution of GA resolution 194 of December 11, 1948, which envisaged the repatriation of the refugees and/or their resettlement in their host countries as part of a comprehensive peace settlement to be mediated by a soon-to-be-established three-member UNCCP (Conciliation Committee for Palestine) ${ }^{7}$. Following this resolution, the UN allocated over $\$ 100$ million to a "reintegration fund which shall be utilized for projects requested by any government in the Near East and approved by the agency for the permanent re-establishment of refugees and their removal from relief" ${ }^{\prime 2}$. The declared goal of the GA was to remove the 1948 Palestinian refugees from relief and re-integrating them as soon as posible in their host Arab countries, following the model of the reintegration of the Jewish refugees and other refugee groups from WWII. As early as the late 1950s, the majority of the original 1948 refugees and their families began to move out of the camps that UNRWA constructed and resettle in neighboring states and regions, or in permanent urban dwellings built by UNRWA in the West Bank and $\mathrm{Gaza}^{9}$. In addition to the original 1948 refugees, non-refugees from neighboring Arab countries began to join the refugees for economic advantages, especially to receive UNRWA's free services ${ }^{10}$. In the early 1960, following the resettlement of the refugees and the dismantling of the temporary shelters, UNRWA's humanitarian mission should have been terminated. Instead, UNRWA continued its operation, issuing informal refugee ID cards, to its clients, refugees, and non-refugees alike. Since humanitarian aid became redundant, UNRWA's bureaucracy shifted its operation to non-emergency civil services. It began to build schools, kindergartens, health clinics, and community centers, providing non-relief civil services to the Palestinian

\footnotetext{
7 UNGA res. 194 (III), December 11, 1948, paras 2, 11.

${ }^{8}$ UNGA res. 393 (V), December 2, 1950, para. 5.

9 The only exception has been Lebanon that due to the delicate ethnic balance between Christian and Muslims in Lebanon, refused to integrate the Palestinian refugees.

10 “The Jalazon data show that half of the camp's household arrived from 1950 onward... and since then the movement into camps continued at a steady annual rate of about 1 percent... most of the families had never been in a camp and decided to move in because of advantages to be gained". Yoram Ben Porat and Emanuel Marx, "Some Sociological and economic aspects of refugees camps on the West Bank”, A Ford Foundation Report. (Santa Monica, Rand Corporation, August 1971).
} 
community. UNRWA's changed agenda was not mandated by GA, rather, the new agenda has been presented to the GA as fait-a compli on the ground, and the GA approve it after the bureaucratic pathologies, namely, the agency fact. James G. Lindsay says that "There is no logical or humanitarian argument to justify a UN organization providing services such as education, and welfare to citizens of a member state in a non-emergency situation” (Lindsay, 2009). In 2014, UNRWA has a work force of 30,000 Palestinians, 15\% of them teachers, while the international staff is about 120 persons. UNRWA's survival is dependent on the perpetuation of the myth of "Right of return of Five Million Palestinian Refugees"; a myth that provides the raison d'etre for the agency's mammoth Palestinian bureaucracy ${ }^{11}$. After 65 years of existence, UNRWA has become an ineffective self-serving, work-creating agency suffused with favoritism and patronage (Lindsay, 2009).

Thus, the two major claims, i.e., that the five million Palestinian descendants of the 800,000 thousand 1948 refugees are refugees by family affiliation, and the second claim that they are stateless, are both a perpetuated myth. The Palestinians of 2014 have ceased to be refugees three generations ago, but with the help of UNRWA, the myth has been perpetuated and accepted as fact. The self-categorization of the Palestinians as refugees, sets them apart from other Arab people, namely, Jordanian, Syrian, Lebanese, etc., and has indeed become a national identity.

\section{The Birth of a Palestinian Refugee ID Card}

The Palestinians consider their UNRWA ID card as crucial representation of their national identity. While refugees, by definition, aspire to terminate their refugee status, the Palestinians proudly hold on to their refugee identity. An examination of this is unique phenomenon that reveals interesting facts. The Palestinians are the only people that possess a UN refugee ID card. No refugee in the world holds a UN card identifying them as “refugees". In fact, neither UNRWA, nor the UNHCR, or any other non-state political entity has the authority to award a refugee status to people who fled their homes in times of war. This is true in particular concerning the 1948 Palestinian refugees, since many of them never crossed any international border and they moved to territories within the traditional Mandatory Palestine (West Bank and Gaza). Thus, they were internally displaced persons, not refugees ${ }^{12}$. The legal practice of awarding refugee status to applicants is the prerogative of the sovereign state that has the legal right to award a "refugee status" to individual foreigners who entered their country. For 65 years, UNRWA has been issuing a pseudo-legal ID document, bestowing "refugee status" on millions of persons who should not be considered refugee by any international measure. While the ID card has no legal value, it has psychological, social, and financial value. In 1948 refugees, the ID card signified the person's eligibility to humanitarian services and physical protection. It should be noted that the 1948 refugees were not included and were not covered by the International Refugee Convention of 1951, since UNRWA was established in 1949, and was expected to protect and provide the refugees with all the benefits promised to refugees in the Convention ${ }^{13}$. It was assumed by the UN General assembly that UNRWA will be dissolved in the 1950s after the resettlement of the refugees in the Arab states ${ }^{14}$. However, the Arab states rejected the

\footnotetext{
${ }^{11}$ UNRWA has accumulated a billion dollars in a pension fund, the "Providence Fund", controlled by the Commissioner General, and never mentioned in the Agency's Annual Report.

12 International law would consider their descendants neither IDPs nor refugees.

13 "The convention also does not apply to those refugees who benefit from the protection or assistance of the United Nations agency other than UNHCR, such as refugees from Palestine who fall under the auspices of the United Nations Relief and Work Agency for Palestine Refugees in the Near East (UNRWA)”, The Refugee Convention, p. 4.

14 The estimated year of completion of resettlement was 1952. See discussion in Nitza Nachmias (2009).
} 
resettlement plans and preferred to perpetuate the refugees' stateless status. Despite the fact that a slow process of settlement of the 1948 refugees occurred, UNRWA's operations were never terminated. It was beneficial for both UNRWA and the Arab states to ignore the resettlement and perpetuate the myth of the Palestinian refugees. Most importantly, UNRWA has consistently and diligently issuing refugee ID cards to persons who by the rules and norms of the Refugee Convention have never been or are not now, refugees. UNRWA's ID cards that were issued originally as a bureaucratic measure to separate eligible and non-eligible clients, have become a national ID card, bestowing upon the holders of the card and their current and future descendants the identity of a "refugee". The self-categorization of the Palestinians as refugees differentiated them from other Arab groups (Jordanian, Syrian, Egyptian, etc.) and assigned them a special political role, to liberate Palestine from the Jews and return the land of Palestine to its rightful owner, the Palestinian people. UNRWA actually enabled the ID cards to become a political document asserting the claim of the "right of return". The descendants of the 1948 refugees continue to categorize themselves as "refugees", they preserve the narrative of the "right of return" and see themselves as if they personally fled their forefathers villages in 1948.

The truth is that for 65 years the applicants for an ID card were hardly vetted. The 1948 recipients of the refugee ID were not required to provide proof of residence, loss of home or livelihood, or a threat to the life of the holder of the card. A simple statement by the applicant that he/she has been refugees was accepted as proof. The lax allocation of refugee ID cards was caused by the belief that UNRWA will be phased out in the early 1950s, and the ID cards will be useless. This assumption proved to be not only wrong, but a tragic act of history. While the third and fourth generations of the descendants of the original 1948 refugees have been absorbed and settled in their host countries or in third countries, and most of them are neither needy nor stateless, they never gave up this informal document, attesting to their refugee status. As a general practice, every Palestinian newborn, anywhere in the world, regardless of their legal residence can receive a refugee ID card upon request, no questions asked. After 65 years, the number of card holders grew exponentially and the narrative of the "statelessness and the right of return" gained more weight. During the years, UNRWA's refugee ID card has been used as an important legal document awarding the holder of the card political and financial rights. The most important right claimed by the Palestinians is the "Right of Return", as well as financial claims for restitution. Unlike the Palestinians, no descendants of post WWII refugee groups that roamed Europe in 1948 ever claimed the "right of return" to the European countries from where their forefathers fled. Today's UNRWA card holders are no different from the third and fourth generation of Holocaust survivors who cannot demand and will never receive the "right of return" to France, Germany, Italy, or any other country from where their ancestors escaped for fear of their live, and became refugees.

This anomaly is a result of the mutual dependence syndrome that has developed between UNRWA and its Palestinian clients. For the Palestinian, being a "professional refugee", is a badge of honor, a membership card in a prestigious club, that could one day even yield some economic benefits. For UNRWA, it is a survival measure; as long as the Palestinians agree to be the bearers of the "refugee" label, the agency's existence is secured. While the work of UNRWA was very important in the early years, when the agency built shelters to the homeless and provided food and medical care to the original refugees of 1948, its practice of printing and disseminating pseudo-legal refugee ID cards is detrimental to the Israeli-Palestinian relationships and the resolution of the issue of "the right of return" (Malkii, 1992). 


\section{Refugee Status and Palestinian Identity}

Identity is defined as "the distinctive characteristics of a person's or group's character that relates to who they are and what is meaningful to them. Some of the main sources of identity include gender, sexual orientation, nationality or ethnicity and social class” ${ }^{15}$. A person develops a self-concept or a self-identity during his formative years, and this identity is based on his relationships with his environment. While self-identity and social identity are two different concepts they are related in their formations and consequences. When an individual takes on an identity, he/she also takes on a social identity. This group-based identity creates a uniformity of perceptions and actions among the members of the group, while it also results in role-based identity that the individual members of the groups adopt. The role-based identity leads to different perceptions and actions among the members of the group, while maintaining and sharing the social identity of the group. The Palestinians clearly share the social identity of the group when they define themselves as "refugees", while simultaneously they develop different role-based identities. The environmental influence on the Palestinian self and role identities is used by the leadership and by UNRWA to sustain the refugee narrative. Four generations after the 1948 exodus, the Palestinians, both in the Middle East and the diaspora still define themselves as a "community of refugees". The refugee ID card serves as a social and communal identity card issued to every new born member of the club. The social identity of the Palestinians is a source of strength and efficacy among the Palestinian members. It also activates a sense of worth and dignity, compensating for their sense of military weakness vis-à-vis Israel. The role-based identity allows the descendants of the 1948 refugees to believe that they are actually the evicted persons, and they have the legitimate right of return.

The UNHCR states: "A stateless person is someone who is not a citizen of any country. Citizenship is the legal bond between a government and an individual, and allows for certain political, economic, social and other rights of the individual, as well as the responsibilities of both government and citizen"16. The Palestinian community intransigent insistence on "I am a refugee" is in complete contrast to the behavior and the state of mind of past and present refugees. A refugee is usually a homeless, stateless, persecuted, oppressed person, yearning to be accepted by a country that will bestow upon him nationality, dignity, safety, and human rights. In addition to sovereign countries who agree to accept refugees, the UNHCR and other refugee support NGOs provide the homeless, stateless suffering persons with shelter, food, medical care, and personal safety. No one has succeeded to express in a few words the state of mind and the physical state of refugees better than Emma Lazarus: "Give me your tired, your poor; Your huddled masses yearning to breathe free; The wretched refuse of your teeming shore; Send these, the homeless, tempest-tost to me, I lift my lamp beside the golden door!”17 Indeed, refugee groups show hostility and resistance to the legal designation of "refugees" and these intense negative feelings serve as strong motivations for nationalism in displaced groups.

It seems that "Palestinian identity" is strongly influenced by a sense of victimization, which is evident by displacement and manifested as a collective nationalistic identity (Clemens, 2007). Based on identity theory, Elbedour at al. (2006) explain that "Identity is a cognitive scheme closely related to specific definitions in which we find ourselves". Why do the Palestinians insist that their nationality is a "nation of refugees"? Why do they hold on to the faux UN refugee ID card as their personal and national identity? Michaela Clemens

\footnotetext{
${ }^{15}$ Anthony Giddens, Michell Duneier et al., Introduction to Sociology, New York: WW Norton, 2000, p. A5.

16 The UNHCR homepage.

17 “The New Colossus”, by Emma Lazarus.
} 
(2007) argues that, "In the case of the Palestinian refugees, identity is not only influenced by displacement, it is reinforced by how Palestinians view themselves and how the outside world views the Palestinians”. The Arab world, with the support of Islamic countries such as Pakistan and Iran, does not wish the Israeli-Arab conflict to be resolved until and unless the Palestinians establish a sovereign Palestinian state on most of the land of the West Bank and perhaps beyond. To achieve this ambitious long standing political goal, it is necessary to keep the myth of millions of displaced Palestinian refugees alive. The Palestinian social identity as a "nation of refugees" permeates all levels of society. Mi'ari's research shows this fact clearly: "The key components of self-identity (among Palestinian youth, N.N.) have a hierarchical order: this group of people identifies themselves first and foremost as Palestinians (national identity), followed by local identity (place of residence), Arab Identity, religious identity, and lastly clan identity" (Mi'ari. M., 1998). The "refugee status" creates solidarity and national identity among the Palestinians, a feeling that is strengthened in response to a real or imagined threat from the enemy, Israel. While Palestinian identity is fragmented along lines of geography, experience, and legal status, a collective identity and a sense of unity is formed in response to the existence of Israel. The inter-group identity is manifested in strong Palestinian nationalism that increases with the level of conflict. "This nationalistic collective and individual identity of Palestinians may prove to be the strongest barrier to peace. The conflict is viewed in Zero-Sum terms, where each side holds the view that only one can be a nation: Either we are a nation or they are. They can acquire national identity and rights only at the expense of our identity and rights" (Salman Elbadour, 2006, p. 218). The strong sense of "we" against "them" is nurtured and nourished by a strong sense of "nostalgia" about the past, about Palestine before 1948 when the Arabs were the majority and the Jews were the minority. A strong attachment to the past and the nurturing of a narrative that glorifies the lost land, the victimization, the agony of displacement, this narrative is transferred from generation to generation focusing on the condition of "statelessness", injustice and expulsion.

\section{How Palestinian Children in the Diaspora Develop Their Refugee Identity}

The identification with the "refugee syndrome" is shared almost unanimously by every Palestinian child in the Middle East and beyond. "My heart is Palestinian, my passport is Jordanian", answered an 11 year-old refugee boy, as he was asked by the researcher Laure Bjawi-Levine about his nationality. Khaled, a 12-year-old said, "I am a Palestinian registered refugee with a Jordanian passport. Others from the group offered similar replies" (Bjawi-Levine, 2009). The children live with the legal paradox—simultaneously refugees and citizens of Jordan, enjoying a Jordanian legal status and recognition, while carrying in their pockets an UNRWA refugee ID card, as a badge of honor. Bjawi-Levine research focused on the issue that is raised here: How do Palestinians in Jordan, who have been living in Jordan with their families for generations, still maintain their refugee identity? How do they make sense of the paradox of their identity? Why children who never visited Palestine, who are fully integrated socially and economically in the Jordanian society, still claim the status of Palestinian refugees? The concept of "social identity" could perhaps help to explain how these Jordanian youths act and feel the way they do. Social identity is one's sense of self as a member of a social group (or groups). According to social identity theory, people classify themselves and others as belonging to specific groups. People regard groups more like themselves more positively, identifying themselves as members of such groups in contrast to others. For example, preferring certain values, one might identify oneself as a conservative as opposed to a liberal. Some sociologists believe social identity can explain extreme behavior. A gang member, for example, might kill someone because the gang member identifies himself or herself as a member of a specific gang as opposed to another. 
Perhaps the key to understanding this binary attitude to the "self" (Jordanian and Palestinian), is to assume that there is more than "one self". The Palestinian self emerges within a complex, differentiated society, reflecting the dictum that the "self reflects society". It is possible that a person' identity will have different roles or different relationships to other persons within society. For example, a teacher will have an identity of a teacher in relationships to his students, while he is a colleague to his fellow teachers. The Palestinian children feel that society expects them to adopt the identity of a "refugee" while they are Jordanian kids to their neighbors and friends. Bjawi-Levine's research focuses on the role of education in creating this duality in identity. "The camp (in Jordan, N.N.) has epitomized for four generations the Nakba, the loss of land-hence of dignity... The Palestinian community views the 'refugee narrative' as a bastion of Palestinian memory and identity" (Bjawi-Levine, 2009, p. 78). The children say that they are "Jordanian outside and Palestinian inside”. This binary identity is transmitted through the family, the clan, and the community from generation to generation. Thus, shedding the title "refugee" means turning your back, on your community, even betraying Palestinian heritage, Palestinian history, nationalism, and pride.

The fact that after six decades of living outside of Palestine, the Palestinians children that continue to hold on to the "refugee identity" is unpatrolled in the history of displacement. Rosemary Sayegh offers a three layered educational strategy used to achieve this goal:

(1) Place of origin in Palestine: This was still a marker of belonging through particularities of food preparations, accent, custom, camp residence, and local memories;

(2) Original class in Palestine, whether urban or rural, land-owner or landless, schooled or illiterate... Original class was still alive in camp relationships for example in marriages-making;

(3) Traces of political attitudes, from pre-48 Palestine still existed in the 1960s, taking forms such as opposition to political parties in general as harmful to national unity, or in partisanship for Hajj Amin Husseini as opposed to the PLO... These pre-48 differentiations weigh heavily in prestige and influence more than land ownership (Sayegh, 2012).

It is clear that the Palestinian community has been making intense efforts to pass on the "refugee narrative" from one generation to the next. "The Right of Return" is arguably one of the central aspects preventing a resolution of the Palestinian-Israeli conflict, and one that stirs debate (Richter-Devroe, 2012). Richter-Devroe research focused on Palestinian who defined themselves as refugees although they were four generations removed from the 1948 refugees. Richter-Devroe asked the children two questions:

(1) What does return (and/or the village/place of origin) mean to different refugees?

(1) How exactly do different refugees envisage return, and thus their Palestine-projects?

Answers to these questions differ widely. It seems that the answer was influenced and shaped by the person's socio-economic class, gender, generation, and political context; however, they were all united in their demand that the right of return is inalienable and must be recognized (Richter-Devroe, 2012, p. 104).

The "right of return" narrative has been closely related to the "victim narrative", and the "victim narrative" enables the perpetuation of the "refugee narrative". Thus, the two narratives: "being a refugee" and "being a "victim" are interdependent and reinforce each other. The refugee is a victim, and the victim became a refugee. The following argument is: The refugee problem will not be resolved until justice will be carried out to remedy the injustice inflicted on the Palestinian victims. As long as the Palestinian are refugees, the injustice that was perpetrated on them during the 1948 Nakbah, has not been remedied. Consequently, the Palestinians have to hold on to their "refugee status" to get justice. 
The majority (of the Palestinian interviewed by Kristine Beckerle) equated justice with the "Right of Return". When claiming that justice was the Right of Return, my interviewees were not only referring to the physical land lost. Rather, return referred to the much broader claim for the restoration of life as it has been, metaphoric return to the conditions lost rather than a physical move to previous properties... These was not merely wishes referring to an idealized notion of how life should be, but rather specific justice claims tied to crime of the refugees' initial displacement. (Beckerle, 2012)

Clearly, the Palestinians who were interviewed, never lived in these idealized lands, and were never displaced. The "victim" narrative and the feelings of injustice and victimization are nurtured and repeated in every UNRWA's school and in every Palestinian home. The association of the "victim" concept with a traumatic experience results in a very strong emotional reaction. "The emphasis has been on responding to trauma, which can follow the experience of being subjected to violence, perpetrating violent acts, bearing witness to violence, or being part of a community that has been mistreated or attacked by another community" (Beckerle, 2012, p. 39). In the Palestinian refugee narrative, the image of the Palestinian child as a victim is part of the historical chronicle of the 1948 Nakba. It is being kept fresh in the minds of the descendent who feel that they fled their homes and they are actually the victims of the trauma of 48. Only rarely are other voices being heard, for example: Kristine Beckerie interviewed Palestinians in the West Bank and she quotes Laila, a 35 year-old women from the West Bank: "The refugees are sick of being the quintessential refugee question for all of these years. They just want to live and to be allowed to live” (Beckerle, 2012, p. 39). This is especially true in Jordan, where over $70 \%$ of the local population has been of Palestinian origin. However, the Arab league rejects and ignores the fact that the descendants of the 1948 exodus have been resettled. Since 1948, the Arab league resolutions prevented the naturalization of Palestinian refugees. "For example, marrying a female citizen of a host country would not bestow residency rights to either husband or their children. And children born in host states could not claim host nationality, although they are afforded refugee status under UNRWA mandate"18. Moreover, "by keeping Palestinians not just as refugees, but as an exceptional, collective case of refugees, the Arab states can keep international attention on their primary goals of repatriation to Palestine and compensation to Palestinian by Israel” (Clemens, 2007, p. 102).

Young, poor Palestinian might think that keeping the UN refugee ID card will eventually yield financial compensation. A Palestinian young man in Jordan was honest to say: "Why don't have this (compensation) money? I am 23 years old and if my little brother asks for money, I can’t give him anything. How do I explain this to him? He believed that restoration of that which had been taken, as well as that which had been lost in terms of opportunity and potential must be restored” (Beckerle, 2012, p. 45). Clearly, the 23-year-old Jordanian guy was never displaced from Palestine, and did not lose opportunities due to the 1948 Nakbah. However, maintaining the identity of "a refugee" could prove to be profitable one day. Why not play the victimized refugee? But the possibility of gaining a windfall of questionable future economic benefits can hardly explain the strong social identity of the Palestinian youth in the Diasporas. We argue that the expected financial compensation is not a major component in the Palestinian attitudes and actions. The literature shows that the majority of the Palestinians place non-material losses ahead of material losses. They feel that the Nakbah and the displacement of 1948 robbed them of their national identity and this is much more important to them than the land lost. They believe that the only way to restore their Palestinian identity is to perpetuate the identity of refugees.

The Arab countries have been exploiting the metaphoric images connecting the "refugees" to the lost land. The practice of linking people to place, nation or territory is not simply territorializing, but is deeply

18 see UNRWA website. 
metaphysical. "People often think of themselves as being rooted in place and as deriving their identity from that rootedness... More broadly, metaphors of kinship (motherland, fatherland, Vaterland' patria...) and of home (homeland...) are also territorializing in the same sense... Thinking about nations and national identities may take the form of roots, trees, origins, ancestries, racial lines, etc.” (Malkki, 1992). It is therefore not surprising that the Palestinians talk in terms of being uprooted, and they have to be re-planted in their homeland.

\section{Conclusion}

In the 20th century, millions of people became refugees, being forced to leave their homes due to violence and wars. Generations of children have been growing up in countries far away from the birthplace of their families. The United States, West Europe and South America, among other states, have been seeing waves of refugees seeking asylum and wishing to build a new life in safety and comfort. The second and third generations acquired the national identity of the country of their residence and did not define themselves as "refugees". Adolescence spans a period of identity crisis (Erikson, 1968), a passage to adulthood marked by major physical, emotional, and social changes. An essential task of development during this time of heightened self-consciousness, when the self-concept is most malleable, is the formation of a healthy sense of identity (Rosenberg, 1979, as cited in Rumbaut, 1994). This statement could explain the Palestinian unique duality of the Palestinian national and personal identities. From early childhood, Palestinian children are socialized to adopt the identity of "refugees", and idealizing of returning to the homeland of their distant ancestors. These youths have been molded by their social contexts and have developed a self-concept, self-regard, and self-identity based on the refugee-narrative. Our attention has been on social context inside and outside the family that may have influenced modes of ethnic and national self-definition and self-identification. How the young Palestinian feel about themselves is critically affected by the parents' modes of ethnic socialization and by the strength of the attachment that a child feels to the parents and to the parents' national origin. Ethnic self-identity is, among other things, a measure of the degree of the children's sense of identification with their parents. We believe that a mechanism of psychological adaptation exists that reduces, or even eliminates contextual dissonances, such as the duality in national loyalty. The perpetuation of the "refugee narrative" built on the solid base of the "victim narrative", helps to resolve this unique and unrealistic condition. Palestinian children in the process of constructing and crystalizing a personal and social identity are challenged to incorporate what is "out there" (Old Palestine) into what is in here (their place of birth and current residence), often in dissonant to their current social context. Palestinians everywhere unanimously agree that the "Right of Return" is an inalienable right and it is the building bloc of the Palestinian nationalism. They feel that giving up the refugee identity could lead to the elimination of the Palestinian identity and nationality. Thus, the UN refugee ID card can't be discarded, and has become a status symbol, a symbol of national pride, and of Palestinian nationalism.

\section{References}

Beckerle, K. (2012). Pity versus rights recognition: Rejection of the victim label by Palestinian refugees. In S. Miari (Ed.), Palestinian refugees: Generations, but one identity (pp. 39-64). Jerusalem: Birzeit University.

Bjawi-Levine, L. (2009). Children's rights discourse and identity ambivalence in Palestinian refugee camps. Jerusalem Quarterly, Spring(37), 75-85.

Clemens, M. S. (2007). The influence of the refugee status on Palestinian identity and the impact of identity on durable solutions to the refugee problem. Nebraska Anthropologist, 22, 97-112. 
David, H. P. (1969). Involuntary international migration: Adaptation of refugees. International Migration, 7(3/4), 67-81.

Kristine, B. (2012). Pity versus rights' recognition: Rejection of the victim label by Palestinian refugees (pp. 39-63). In S. Miari (Ed.), Jerusalem: Birzeit University.

Lindsay, J. G. (2009). Fixing UNRWA: Repairing the UN's troubled system of aid to Palestinian refugees (p. 53). The Washington Institute.

Malkii, L. (1992). National geographic: The rooting of peoples and the territorialization of national identity among scholars and refugees . Cultural Anthropology, 7(1), 24-44.

Mi'ari. M.(1998). Self-identity and readiness for interethnic contact among young Palestinian in the west bank. Canadian Journal of Sociology, Winter 98, 23(1), 47-55.

Michaela, C. (2007). The influence of the refugee status on Palestinian identity and the impact of identity on durable solutions to the refugee problem (p. 102). Nebraska Anthropologist.

Nachmias, N. (2009). UNRWA at 60: Are there better alternatives? Middle East Forum, October 12.

Richter-Devroe, S. (2012). Return narratives of Palestinian refugees in the west bank: A generational perspective. In S. Miari, (Ed.), Palestinian refugees: Generations, but one identity Jerusalem (pp. 103-118). Birzeit University.

Rumbaut, R. G. (1994). The crucible within: Ethnic identity, self-esteem, and segmented assimilation among children of immigrants. International Migration Review, 28(4), 753.

Salman, E. (2006). Terror in the Holy Land (p. 218). Greenwood Publishing.

Sayegh, R. (2012). Palestinian refugee identity/ies: Generation, religion, class. In S. Miari (Ed.), Palestinian refugees: Generations, but one identity (p. 15). Birzeit University. 